$1-1-1988$

\title{
Fuel consumption for kiln drying Appalachian hardwoods
}

James P. Armstrong

Samuel M. Brock

Follow this and additional works at: https://researchrepository.wvu.edu/ wv_agricultural_and_forestry_experiment_station_bulletins

\section{Digital Commons Citation}

Armstrong, James P. and Brock, Samuel M., "Fuel consumption for kiln drying Appalachian hardwoods" (1988). West Virginia Agricultural and Forestry Experiment Station Bulletins. 698.

https://researchrepository.wvu.edu/wv_agricultural_and_forestry_experiment_station_bulletins/592 @ WVU. It has been accepted for inclusion in West Virginia Agricultural and Forestry Experiment Station Bulletins by an authorized administrator of The Research Repository @ WVU. For more information, please contact ian.harmon@mail.wvu.edu. 


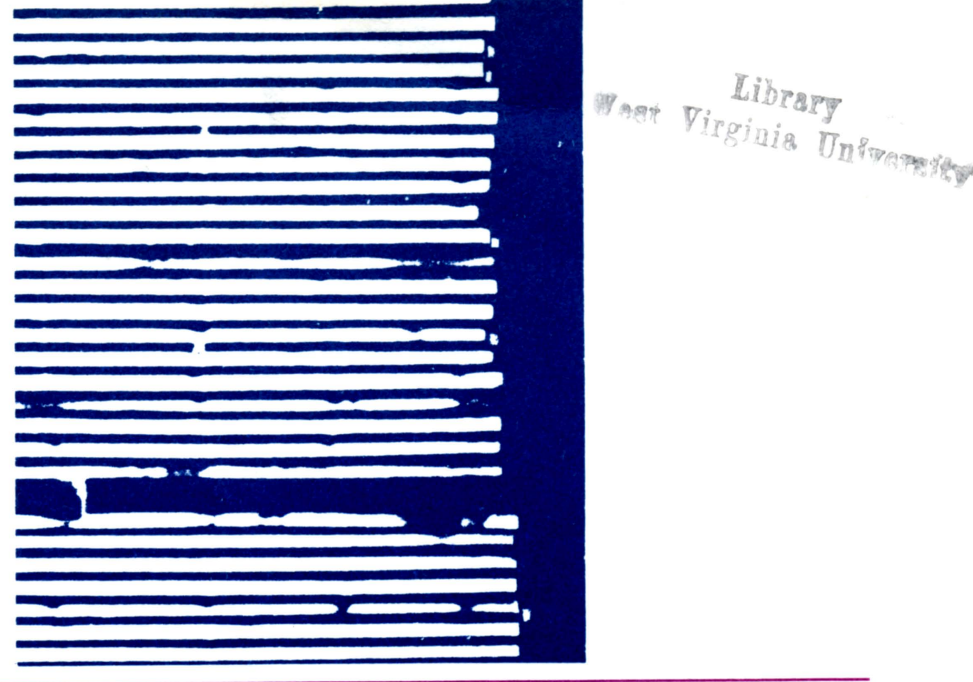

\section{Fuel Consumption for Kiln Drying Appalachian Hardwoods}

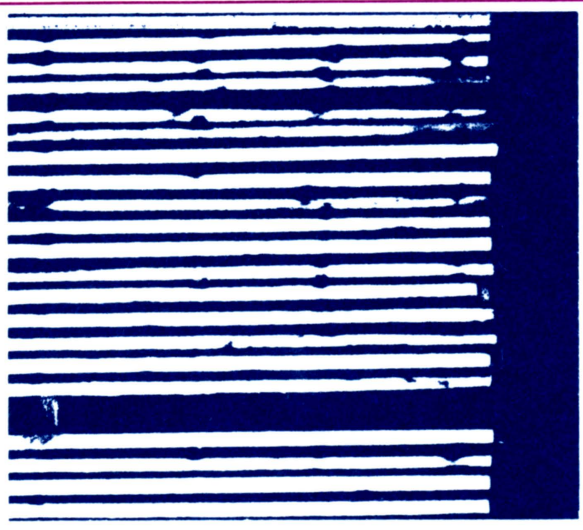

\section{Bulletin 698 \\ March 1988}

Agricultural and Forestry Experiment Station West Virginia University

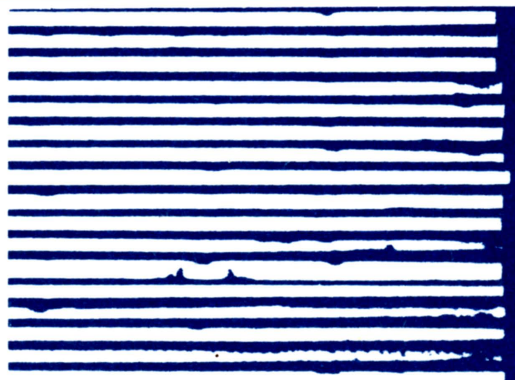


Authors

James P. Armstrong is associate professor of wood science and Samuel M. Brock is professor of forest management, Division of Forestry, College of Agriculture and Forestry, West Virginia University.

\author{
WEST VIRGINIA UNIVERSITY \\ AGRICULTURAL AND FORESTRY EXPERIMENT STATION \\ COLLEGE OF AGRICULTURE AND FORESTRY \\ ROBERT H. MAXWELL, DIRECTOR \\ MORGANTOWN
}




\section{Contents}

Preface iii

Abstract iii

Methods 2

Variables Affecting Fuel Consumption 3

Estimating Fuel Consumption 4

Response to the Survey 6

Fuel Consumption 6

Localized Patterns inDrying and Fuel Consumption 8

Conclusions 9

Literature Cited 11

Appendix 13 
[Blank Page in Original Bulletin] 


\section{Preface}

This research was sponsored by a grant from the West Virginia Fuel and Energy Office, Governor's Office of Community and Industrial Development, and the U.S. Department of Energy, Southeast Regional Biomass Energy Program.

\section{Abstract}

A study of fuel consumption trends for drying lumber was conducted in the central Appalachian region. Data on the equipment, capacities, productivity, and consumption of fuel for kiln drying were gathered in a 1986 survey.

A total of 129 mills provided usable data for the study. They operated 701 kiln units and kiln dried approximately 593 million board feet of lumber annually. Wood residues were used as either the principal or secondary fuel stock by 64 percent of the mills included in this study. Natural gas was used as either the primary or secondary fuel by a total of 19 percent of the mills, and fuel oil was either the primary or secondary fuel for 14 percent. Coal was also used by some mills, mostly in combination with wood residues. Approximately 11 percent of the mills operated dehumidification kilns which consumed electricity.

The region included in the study area was divided into seven smaller geographical areas and localized trends in fuel consumption were analyzed. These areas included eastern Kentucky, southeastern Ohio, southwestern Pennsylvania, western Maryland, western Virginia, northern West Virginia, and southern West Virginia. The number of mills consuming each fuel to heat their dry kilns, production of kiln dried lumber by mills using each fuel, and the estimated or reported consumption of each fuel has been tabulated within each of the seven areas. 
[Blank Page in Original Bulletin] 


\section{Fuel Consumption for Kiln Drying Appalachian Hardwoods}

\section{James P. Armstrong and Samuel M. Brock}

One of the principal uses of wood residue in the forest products industry is as boiler fuel for drying lumber in steam kilns. Drying is the most energy-intensive process in the manufacture of hardwood lumber. It is estimated that 60 to 70 percent of all energy used in lumber manufacture is consumed for this purpose (Comstock 1975). In a study of kiln drying practices in the West Virginia lumber industry (Armstrong 1987), it was found that approximately 90 percent of the dry kilns in the state were steam heated and three types of fuels were used to fire the kiln boilers. Of these three, coal accounted for a very small percentage of the energy requirements. The principal fuels were woody biomass (residue from processing operations) and natural gas.

Generation of wood residue in a sawmill is the inevitable result of both sawing lumber from logs and processing lumber into clear products of finished sizes. Residues generated include bark, sawdust, planer shavings, and solid residue or chips from slabs, edgings and end trim. Disposal of residue can be a tremendous environmental and logistical problem for sawmills and secondary wood products manufacturers. The West Virginia University Cooperative Extension Service reports that this is a particularly serious problem in several southern West Virginia counties (Patterson 1985).

However, the residues of lumber and solid wood product manufacture, particularly sawdust and bark, are frequently used as fuel for kiln drying operations. Use of mill residues for this purpose is an attractive alternative to fossil fuel due to availability, renewability, and low cost of this resource. In order to facilitate planning for better use of the wood residue resource, better information is needed to identify the level and location of residue consumption in kiln drying operations in the central Appalachians.

It was the goal of this study to determine consumption of wood residue for fuel in kiln drying operations in the central Appalachian region and to iden- 
tify significant factors that influence consumption of residue and other fuels. Data were collected from central Appalachian lumber drying operations regarding types and capacity of drying equipment, fuel consumption patterns, and production of kiln dried lumber. In addition, the extent of kiln drying activity and fuel consumption within areas of the region was examined.

\section{Methods}

Information was gathered with a survey of kiln operations in West Virginia and the counties of Pennsylvania, Maryland, Ohio, Kentucky and Virginia that lie within 125 highway miles of the West Virginia border. Mill listings were obtained from cooperative extension services and state departments of forestry or natural resources. A total of 227 mills were identified as operating dry kilns or as having a strong likelihood of operating dry kilns.

The survey was conducted by mail and employed the "Total Design Method" (Dillman 1978). The investigators also visited a number of mills in order to collect data and pretest the survey questionnaire. The initial survey was sent by mail on August 29, 1986, and included a questionnaire, a cover letter explaining what the survey was to accomplish, and a self-addressed, postagepaid business reply envelope. A series of mail and telephone follow-ups took place after the initial mailing. The first follow-up was a postcard, mailed one week after the initial mailing, to all of the mills thanking them in advance for their response and reminding those who had not responded to please do so. The second follow-up, four weeks after the initial mailing, was sent to all mills that had not yet responded and it included a questionnaire, cover letter, and business reply envelope. The final mailing took place seven weeks after the initial mailing, and was sent by certified mail to all mills that had not yet responded. This mailing also included a questionnaire, cover letter, and business reply envelope. In January of 1987, those mills that had still not responded were contacted by telephone. The follow-ups, as suggested by Dillman (1978), were designed to maximize the number of responses to the survey.

Specific data collected from each operation included: number of kilns, kiln capacity, number of board feet of lumber kiln dried annually, and the kind of fuel used. If residue was burned as fuel, the number of tons of bark, sawdust and chips produced and consumed, whether the fuel was wet or dry when consumed, and percentage of residues purchased from other sources were determined. If other fuels were used, the quantity of fuel consumed was determined. 


\section{Variables Affecting Fuel Consumption}

Variables affecting fuel consumption may be divided into three categories: production variables, equipment variables, and fuel variables.

The production variables include the volume of lumber kiln dried and kiln residence time. These factors are dependent upon the product mix of a particular enterprise. This includes wood species, and the lumber thicknesses dried. Denser species generally require greater energy input to remove water from the wood. Refractory species such as red and white oak require longer drying times as does thicker lumber of any species. Since we had to limit the length of the survey questionnaire, product mix information was not obtained. However, information on species dried may be found in a separate study of the kiln drying industry of West Virginia (Armstrong 1987). The production breakdown by species of 30 West Virginia kiln enterprises is illustrated in Figure 1.

The initial and final moisture contents of the lumber are also production variables. Some mills prefer to dry the lumber from its green, or freshly cut, moisture content which is species-dependent (Rasmussen 1961). Other mills air-dry the lumber to approximately 30 to 50 percent moisture content prior to kiln drying. Other mills operate predriers which are heated buildings with controlled air circulation and ventilation. A predrier typically dries lumber to 20 to 40 percent moisture content before kiln drying. The survey determined whether mills were drying green, air-dried or predried lumber. No data were sought on average initial lumber moisture contents for individual mills since this varies considerably within each mill. Final moisture contents are dependent upon the intended end use of the lumber. For most hardwoods, the typical range is between 6 and 8 percent.

Equipment variables are best categorized as boiler and kiln efficiencies. Boiler efficiency, which is expressed as a percentage, is defined as a ratio of the usable heat obtained to the theoretical fuel value or heat of combustion of the fuel consumed. The efficiency of a wood-fired boiler can range from approximately 50 or 60 percent for older boilers to 80 percent for state-of-the-art residue-burning systems. Kiln efficiency, which is expressed as a percentage, is defined as the ratio of heat energy actually consumed to remove water from wood to the quantity of heat energy input into the dry kiln. Kiln efficiency is dependent upon several factors including the species and thicknesses of lumber dried, heat loss due to unwanted leaks from the kiln building, and kiln operator practices such as excessive venting of the kiln chamber. The survey questionnaire asked for boiler efficiencies but few respondents were able to supply this information. Very few kiln operators or mill managers know the efficiencies of their dry kilns. Therefore, kiln efficiencies were not asked for in the questionnaire. 
The most significant fuel variable is the expected quantity of heat (in Btu) produced by complete combustion of a unit measure of the fuel. In the case of wood residue, the heat of combustion can vary greatly depending upon the moisture content of the fuel, and whether the fuel is bark or woody material such as sawdust, shavings, or chips (Panshin and deZeeuw 1980). The most critical factor is moisture content. The survey asked whether residues were burned dry or wet but did not ask for the specific moisture content of fuel burned since this can vary greatly from time to time at each mill. From the survey data, 45 percent of the mills burned wet residue, 37 percent burned dry residue, and 18 percent burned both.

\section{Estimating Fuel Consumption}

It is possible to estimate the quantity of fuel required to kiln dry a given volume of lumber based upon the properties of the wood species to be dried, the efficiency of the boiler and the kiln, and the quantity of heat produced by complete combustion of a unit measure of the fuel to be used. In fact, this procedure is used to estimate fuel requirements for new or renovated kiln equipment.

The quantity of fuel required to kiln dry 1,000 board feet of lumber of a given species may be calculated using the following equation:

$\frac{\text { Quantity of Fuel }}{\mathrm{MBF}}=\frac{\mathrm{Btu} / \mathrm{MBF}}{\mathrm{H}(\mathrm{c}) \times \mathrm{e}(\text { boiler }) \times \mathrm{e}(\mathrm{kiln})} \quad$ [Equation 1]

where: $\mathrm{Btu} / \mathrm{MBF}$ is the quantity of heat required to kiln dry 1,000 board feet of a particular species of lumber; $\mathrm{H}(\mathrm{c})$ is the quantity of heat produced by complete combustion of a unit measure of fuel; $e$ (boiler) is the efficiency of the boiler expressed as a decimal; and e(kiln) is the kiln efficiency expressed as a decimal.

The quantity of heat required to kiln dry 1,000 board feet of a particular species of lumber may be estimated from the following equation (Skaar 1977):

$$
\mathrm{Btu} / \mathrm{MBF}=51.98(\mathrm{G})(\mathrm{Mw}-\mathrm{Md})(\mathrm{Qv})
$$

[Equation 2]

where: $\mathrm{G}$ is the specific gravity of the species based upon its oven-dry weight and green volume; Mw and Md are the wet and dry moisture contents of the lumber expressed as whole numbers, respectively; and Qv is the mean value of Btu required to evaporate one pound of water from wood at 68 degrees Fahrenheit in the range of Mw and Md. Values of G may be found in Rasmussen (1961) and values of Qv may be found in Skaar (1977). 
Some typical heat values of fuels reported in the survey are listed in Table 1. When wood residue is used as the fuel, the heat of combustion must be adjusted for moisture content by use of the following equation (Panshin and deZeeuw 1980):

$$
\frac{\text { Btu }}{\mathrm{Lb}}=\mathrm{H}(\mathrm{c}) \frac{100-(\mathrm{M} \div 7)}{100+\mathrm{M}}
$$

where: $\mathrm{H}(\mathrm{c})$ is the heat of combustion of one pound of oven-dry wood; and $M$ is the moisture content of the fuel expressed as a whole number.

It is helpful in evaluating the survey data to derive estimated values of expected fuel consumption per thousand board feet for what might be considered hypothetical maximum and minimum fuel consumption cases. In order to do this, several assumptions must be made.

In the maximum fuel consumption case, it is assumed that $4 / 4$ inch thick red oak lumber is to be dried from green or from an initial moisture content of 80 percent to a final moisture content of 6 percent. The specific gravity of red oak is 0.55 and its average green moisture content is 80 percent (Rasmussen 1961). The mean value of Btu required to evaporate one pound of water from wood at 68 degrees Fahrenheit in the range of 80 and 6 percent is 1161 (Skaar 1977). By substituting these values into equation 2 , it is calculated that 2.4 million Btu are required to kiln dry 1,000 board feet of $4 / 4$ red oak lumber from 80 to 6 percent moisture content. It is assumed that the fuel is hardwood stemwood residue which is burned at 80 percent moisture content. The residue has a heat value of 15 million Btu per oven-dry ton (Koch 1985). Equation 3 may be used to estimate that the actual fuel value of wet residue is 7.4 million Btu per ton. It is assumed that the kiln efficiency is 33 percent which is not unreasonable for kiln drying red oak, and that the boiler efficiency is 60 percent which is in the low end of typical efficiencies for wood-fired boilers (Bachrich 1980). From equation 1, the hypothetical maximum fuel consumption that may be expected in the central Appalachian region would be 1.6 tons of wet residue per thousand board feet of red oak lumber kiln dried from 80 to 6 percent moisture content.

The minimum fuel consumption case assumes that $4 / 4$ inch thick yellowpoplar lumber is to be dried from a partially air-dried moisture content of 30 percent to a final moisture content of 8 percent. The specific gravity of yellowpoplar is 0.40 based on its oven-dry weight and green volume (Rasmussen 1961). The mean value of Btu required to evaporate one pound of water from wood at 68 degrees Fahrenheit in the range of 30 and 8 percent is 1138 (Skaar 1977). By substituting these values into equation 2 , it is calculated that 0.5 million Btu are required to kiln dry 1,000 board feet of $4 / 4$ yellow-poplar lumber from 30 to 8 percent moisture content. It is assumed that the fuel is hardwood 
stemwood residue at 10 percent moisture content. Equation 3 may be used to estimate that the actual fuel value of wet residue is $\mathbf{1 1 . 6}$ million Btu per ton. It is assumed that the kiln efficiency is $\mathbf{4 0}$ percent which is not unreasonable for a kiln drying yellow-poplar, and that the boiler efficiency is 80 percent which is typical of the efficiency of a state-of-the-art wood-fired boiler (Bachrich 1980). From equation 1, the hypothetical minimum fuel consumption that may be expected in the central Appalachian region would be 0.13 tons of residue per thousand board feet of yellow-poplar lumber kiln dried from 30 to 8 percent moisture content.

Using the same assumptions for species, initial and final moisture contents, and kiln efficiencies, the hypothetical maximum and minimum consumption of fuels for steam kilns may be estimated using equation 1 and the heat values per unit measure given in Table 1 . The results of these estimates are given in Table 2 , as well as an estimated quantity of electricity for dehumidification drying of red oak obtained from the literature.

\section{Response to the Survey}

Responses were obtained from 197 of the 227 sites surveyed, a response rate of 87 percent. Of the 197 mills responding to the survey, 148 are operating dry kilns. One hundred and twenty-nine mills provided data usable in our analyses. Other mills were eliminated for various reasons, the most common being that either they did not supply data on the number of board feet dried or their kilns were not operating in 1985. In addition, several mills were operating solar kilns thus could not provide usable data.

The 129 mills operated a total of 701 individual dry kilns and kiln dried approximately 593 million board feet of lumber annually. Steam kilns were operated by 115 of these mills and dehumidification kilns were operated by 14 .

\section{Fuel Consumption}

Table 3 indicates the number of mills, the number and capacity of the kilns they were operating, and the number of board feet of lumber dried using each fuel or combination of fuels. The breakdown of fuel use by mills is illustrated in Figure 2. Fuel consumption as a function of production of kiln dried lumber is illustrated in Figure 3. Table 4 summarizes the average quantity of fuel used throughout the region to kiln dry one thousand board feet of lumber.

Seventeen mills used more than one fuel to fire their boilers. In most of these cases the mill was operating more than one boiler with different kilns heated by each. Due to the the survey design it was not possible to break down the results in terms of production or number of kiln units for each fuel consumed at a particular site. 
Wood residue is the most economical fuel and it is available in large quantities to most wood-using industries. For example, the cost of producing one million Btu from hardwood sawdust at 50 percent moisture content in a 70 percent efficient boiler would be $\$ 1.43$, assuming a conservatively high residue cost of $\$ 10.00$ per ton (Bachrich 1980, Panshin and deZeeuw 1980). There is a greater cost for handling and storage of residue, and the cost of boilers for burning residue is greater when compared to oil or gas. However, the lower fuel cost will in most cases more than compensate for these additional costs (Walton $e t$ al. 1987).

Thus it is not surprising that wood residue was the most commonly used fuel identified in this study. As indicated in Figure 2, approximately 54 percent of the mills consumed residue as their only fuel. They kiln dried approximately 58 percent of the total lumber produced as illustrated in Figure 3. An additional 10 percent of the mills consumed residue in combination with one or more fossil fuels. Residue was used as either the principal or secondary fuel stock by 64 percent of the mills to kiln dry 85 percent of the annual lumber production. As indicated in Table 4, an estimated 424,870 tons of residue were consumed per year and an average of 0.97 ton per thousand board feet were consumed in the drying process.

The second most commonly used fuel was natural gas. It was the only fuel consumed by 14 percent of the mills to kiln dry 8 percent of the total volume of lumber identified in the survey as illustrated in Figures 2 and 3. Gas was used in combination with other fuels by 5.5 percent of the mills to dry approximately 13 percent of the lumber. Thus, gas was used as either the primary or secondary fuel by 19 percent of the mills to dry 21 percent of the total production. As indicated in Table 4, an estimated 263,560 thousand cubic feet (MCF) of gas were consumed per year and an average of $3.82 \mathrm{MCF}$ per thousand board feet were consumed in the drying process.

A West Virginia gas company charged \$5.82 per MCF in September 1987. Assuming that natural gas produces one million Btu per MCF (ASHRAE 1967) and gas boilers are approximately 80 percent efficient (Bachrich 1980), the approximate cost per million Btu produced by burning natural gas is $\$ 7.28$. In several cases examined in the course of this study, mills owned their own gas wells and were able to provide natural gas at a much lower rate than if they were purchasing it from a utility company.

Fuel oil was the only fuel used by 5.5 percent of the mills which kiln dried approximately 1 percent of the lumber as illustrated in Figures 2 and 3 . However, it was used in combination with other fuels by 8.5 percent of the mills to dry approximately 20 percent of the lumber produced. Thus, oil was either the primary or secondary fuel for 14 percent of the mills which accounted for 21 percent of the annual production of kiln dried lumber. As indicated in Table 4 , these mills reported consuming a total of 1,366,300 gallons of fuel oil per year. 
An average of 44.75 gallons were consumed to kiln dry each 1,000 board feet of lumber.

A fuel oil distributor in northern West Virginia charged 74 cents per U.S. gallon of fuel oil to industrial customers in October 1987. A gallon of fuel oil was assumed to produce approximately 140,000 Btu when burned (ASHRAE 1967) and oil-fired boilers were assumed to be 80 percent efficient (Bachrich 1980). Under these conditions, the cost of producing one million Btu by burning fuel oil was $\$ 6.61$.

Coal was employed most frequently in combination with other fuels, particularly wood residues. As indicated in Figure 2, it was the only fuel used by 2 percent of the mills but was used in combination with other fuels by 4.5 percent. Coal was used as the primary or secondary fuel to kiln dry 18 percent of the total lumber produced as illustrated in Figure 3. A reported 4,590 tons of coal per year were consumed as indicated in Table 4 . An average of 0.18 ton of coal was consumed to kiln dry each 1,000 board feet.

One of the mills surveyed paid $\$ 47$ per ton of coal. Assuming that one ton of coal will produce 25 million Btu (ASHRAE 1967) and that the typical efficiency of a coal-fired boiler is 70 percent, the cost of producing one million Btu by burning coal is $\$ 2.68$.

Dehumidification kilns, which consume electricity, were operated by 11 percent of the mills. They kiln dried only 2 percent of the total volume of lumber identified by this study. Dehumidification kilns operate on a different principle from steam kilns, do not require a boiler, and are very energy efficient in comparison to steam kilns (Wengert 1980). Dehumidification kilns are economically better suited to smaller kiln operations, typically in conjunction with an existing sawmill. Hence, the level of production of mills operating dehumidification kilns would not be expected to be as great as mills operating steam kilns. Also, due to the economies of scale, comparing cost per million Btu for dehumidification kilns with steam kilns is not very meaningful.

\section{Localized Patterns in Drying and Fuel Consumption}

The region included in the study area was divided into seven areas in order to assess local patterns in fuel consumption. These areas were divided along state lines to include those counties of each state within 125 miles of the West Virginia border. In addition, West Virginia was divided into northern and southern areas. The areas studied were: eastern Kentucky, southeastern Ohio, southwestern and south-central Pennsylvania, western Maryland, western Virginia, northern West Virginia, and southern West Virginia. The counties of each state included within each region are illustrated in Figure 4. 
The number of mills operating dry kilns within each region and the fuels they used are shown in Figure 5. Production in million board feet kiln dried annually within regions is illustrated in Figure 6 for each fuel type.

Figure 7 indicates the reported or estimated quantities of each fuel consumed within each region by mills providing usable data. Estimated quantities of fuel were derived by using the linear regression models for wood residue and natural gas consumption (Armstrong and Brock 1987). Due to the lack of data upon which to base estimates for fuel oil, coal, and electricity consumption, only the actual quantities of fuel reported by survey respondents is given in Figure 7.

\section{Conclusions}

Survey responses from 129 mills in the central Appalachian region revealed that they kiln dried approximately 593 million board feet of lumber per year. Steam kilns were operated by 115 of these mills and dehumidification kilns were operated by 14 .

Mill residue was the most commonly used fuel in the region. It was used as either the principal or secondary fuel stock by 64 percent of the mills and was used to kiln dry 85 percent of the annual production of dry lumber. An estimated 424,870 tons of residue was consumed per year which amounted to an average consumption of 0.97 ton per thousand board feet of lumber.

Natural gas was used to a lesser extent than residue. It was used as either the primary or secondary fuel by a total of 19 percent of the mills to kiln dry 21 percent of the lumber dried by the mills surveyed. An estimated total of 263,560 MCF per year of natural gas were consumed by these mills. An average of 3.82 MCF of gas was consumed to kiln dry each 1,000 board feet of lumber.

Fuel oil was either the primary or secondary fuel for 14 percent of the mills that kiln dried 21 percent of the lumber. These mills reported consuming a total of 1,366,300 gallons of fuel oil per year. An average of 44.75 gallons were consumed to kiln dry each 1,000 board feet of lumber.

Coal was consumed as either the primary or secondary fuel by 6.5 percent of the mills to kiln dry 18 percent of the lumber identified by this survey. Every one of the 9 mills consuming coal in combination with other fuels also used wood residues as either a primary or secondary fuel. A reported 4,590 tons of coal per year were consumed by these mills which accounted for an average consumption of 0.18 ton per 1,000 board feet.

Approximately 11 percent of the mills operated dehumidification kilns which consumed electricity as their fuel. These mills kiln dried approximately 2 percent of the total volume of lumber produced.

The widespread use of wood residue is the result of its low cost and ready availability to wood products enterprises. Most of the newer installations of 
steam kilns employ wood-fired boilers and it is expected that this trend will continue. Dehumidification is economically attractive to mills producing less than one to two million board feet per year due to relatively low investment costs of the kilns and equipment. Smaller enterprises in the region, typically sawmills, have installed dehumidification kilns. 


\section{Literature Cited}

Armstrong, J.P. 1987. Kiln Drying of Lumber in West Virginia: An Update. Bulletin (in print). West Virginia Agricultural and Forestry Experiment Station. West Virginia University. Morgantown, W.V.

Armstrong, J.P., and S.M. Brock. 1987. "Demand for Wood Residue by Kiln Drying Enterprises in the Central Appalachians." Unpublished report. West Virginia University. Morgantown, W.V.

ASHRAE. 1967. ASHRAE Handbook of Fundamentals. American Society of Heating, Refrigerating and Air-Conditioning Engineers. New York, N.Y.

Bachrich, J.L. 1980. Dry Kiln Handbook. H.A. Simons (International) Ltd. Vancouver, British Columbia, Canada.

Comstock, G.L. 1975. "Energy requirements for drying of wood products." Proc. No. P-75-13. Wood Residues as an Energy Source: 8-12. Denver, Colo., September 3-5, 1975. Published by the Forest Products Research Society, Madison, Wis.

Dillman, D.A. 1978. Mail and Telephone Surveys: The Total Design Method. John Wiley and Sons. New York, N.Y.

Koch, P. 1985. Utilization of Hardwoods Growing on Southern Pine Sites. Vol. I. The Raw Material. Agriculture Handbook No. 605. U.S.D.A. Forest Service, Southeastern Forest Experiment Station, Pineville, La.

Panshin, A.J., and C. deZeeuw. 1980. Textbook of Wood Technology. Fourth Edition. McGraw-Hill Book Company. New York, N.Y.

Patterson, D.W. 1985. Report of 1984-85 Sawmill Visits. Unpublished report. West Virginia Cooperative Extension Service. West Virginia University. Morgantown, W.V.

Rasmussen, E.F. 1961. Dry Kiln Operator's Manual. Agriculture Handbook No. 188. U.S.D.A. Forest Service, Forest Products Laboratory. Madison, Wis.

Shottafer, J.E., and C.E. Shuler. 1974. Estimating Heat Consumption in Kiln Drying Lumber. Technical Bulletin 73. Life Sciences and Agricultural Experiment Station. University of Maine at Orono. Orono, Me. 
Skaar, C. 1977. "Energy requirements for drying lumber." In Practical Application of Solar Energy to Wood Processing: 29-32. Blacksburg, Va., January 6-7, 1977. Published by the Forest Products Research Society, Madison, Wis.

Walton, D.R., Patterson, D.W., and J.P. Armstrong. 1987. EERS (Economic Evaluation of a Residue System): A Model for Analyzing the Economics of Installing a Steam Kiln and Wood-Fired Boiler at a West Virginia Sawmill. Bulletin 696. West Virginia Agricultural and Forestry Experiment Station. West Virginia University. Morgantown, W.V.

Wengert, E.M. 1980. "Drying at the sawmill with dehumidifiers." Northern Logger and Timber Processor 28(9):20-21. 
Appendix 
TABLE 1. Typical fuel values of wood residues, natural gas, fuel oil, and coal obtained from the literature.

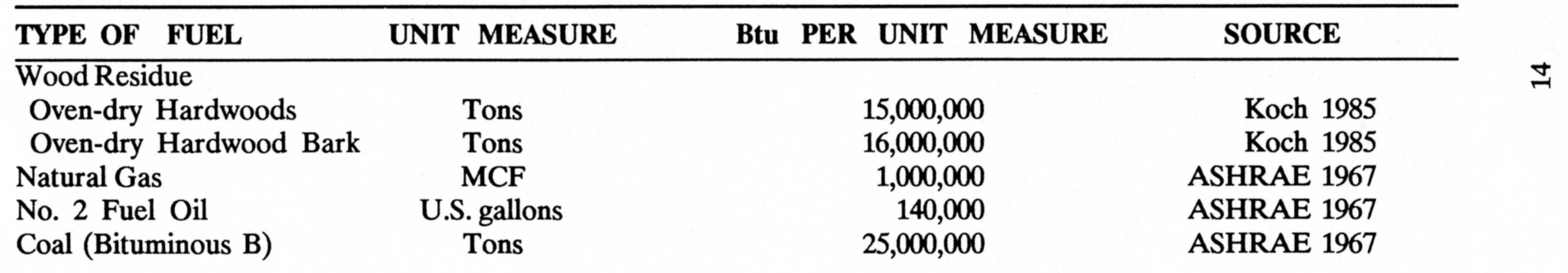


TABLE 2. Hypothetical estimates of the maximum and minimum fuel consumption per thousand board feet of lumber kiln dried.

4/4 RED OAK FROM 80 TO $6 \% \quad$ 4/4 YELLOW-POPLAR FROM 30 TO 8\%

\begin{tabular}{|c|c|c|c|c|}
\hline \multirow[b]{2}{*}{$\begin{array}{c}\text { TYPE } \\
\text { OF } \\
\text { FUEL }\end{array}$} & \multicolumn{2}{|l|}{$\mathbf{4 / 4}$} & \multicolumn{2}{|c|}{ WOW-POPLAK FKOM } \\
\hline & $\begin{array}{c}\text { BOILER } \\
\text { EFFICIENCY }\end{array}$ & $\begin{array}{c}\text { FUEL } \\
\text { CONSUMPTION } \\
\text { PER MBF }\end{array}$ & $\begin{array}{c}\text { BOILER } \\
\text { EFFICIENCY }\end{array}$ & $\begin{array}{c}\text { FUEL } \\
\text { CONSUMPTION } \\
\text { PER MBF } \\
\end{array}$ \\
\hline Wood Residue & $60 \%$ & 1.6 tons & $80 \%$ & $\begin{array}{l}0.1 \text { tons } \\
1.5 \mathrm{MCF}\end{array}$ \\
\hline Natural Gas & $75 \%$ & 9.7 MCF & $85 \%$ & $\begin{array}{r}1.5 \mathrm{MCF} \\
10.5 \text { gallons }\end{array}$ \\
\hline No. 2 Fuel Oil & $75 \%$ & 69.3 gallons & $\begin{array}{l}85 \% \\
80 \%\end{array}$ & $\begin{array}{l}10.5 \text { gallons } \\
0.06 \text { tons }\end{array}$ \\
\hline $\begin{array}{l}\text { Bituminous Coal } \\
\text { Electricity }\end{array}$ & $\begin{array}{r}65 \% \\
---\end{array}$ & $\begin{array}{r}0.4 \text { tons } \\
700 \mathrm{KWH}\end{array}$ & & \\
\hline & & (Wengert 1980) & & \\
\hline
\end{tabular}


TABLE 3: The number of central Appalachian mills providing data for this study, the number of dry kilns they operated, the total capacity of kilns, and the number of board feet kiln dried annually by each of several types of kilns grouped by fuel or combination of fuels consumed.

\begin{tabular}{lcccc}
\hline \multicolumn{1}{c}{$\begin{array}{c}\text { TYPE OF } \\
\text { KILN }\end{array}$} & $\begin{array}{c}\text { NUMBER OF } \\
\text { MILLS }\end{array}$ & $\begin{array}{c}\text { NUMBER OF } \\
\text { KILNS }\end{array}$ & $\begin{array}{c}\text { TOTAL } \\
\text { CAPACITY } \\
\text { OF KILNS } \\
\text { (MBF) }\end{array}$ & $\begin{array}{c}\text { LUMBER } \\
\text { DRIED } \\
\text { PER }\end{array}$ \\
YEAR \\
STEAM KILNS & & & & \\
Mill Residue & & & 20,550 & 345,010 \\
Natural Gas & 10 & 367 & 2,850 & 44,930 \\
Fuel Oil & 7 & 62 & 410 & 4,440 \\
Coal & 3 & 17 & 210 & 4,200 \\
Residue/Coal & 6 & 8 & 4,350 & 58,680 \\
Residue/Oil & 2 & 13 & 720 & 43,400 \\
Residue/Gas/Oil & 2 & 43 & 1,780 & 28,000 \\
Residue/Oil/Coal & 2 & 26 & 1,400 & 22,750 \\
Gas/Oil & 4 & 30 & 1,070 & 12,960 \\
Residue/Gas/Oil/Coal & 1 & 7 & 360 & 13,260 \\
DEHUMIDIFICATION & 14 & 52 & 1,790 & 589,160 \\
TOTAL & & & 35,590 &
\end{tabular}


TABLE 4. Summary of the average quantity of various fuels consumed throughout the region to kiln dry 1,000 board feet (MBF) of lumber and total estimated consumption of fuels by the 129 central Appalachian mills that provided usable data for this study.

\begin{tabular}{lcr}
\hline $\begin{array}{c}\text { TYPE OF } \\
\text { FUEL }\end{array}$ & QUANTITY OF FUEL PER MBF & $\begin{array}{r}\text { TOTAL } \\
\text { CONSTUMPTION }\end{array}$ \\
\hline Wood Residue & 0.97 Tons & 424,870 Tons \\
Natural Gas & $3.82 \mathrm{MCF}$ & $263,560 \mathrm{MCF}$ \\
Fuel Oil & 44.75 Gallons & $1,366,300$ Gallons \\
Coal & 0.18 Tons & 4,590 Tons \\
Electricity & $522 \mathrm{KWH}$ & $(1)$
\end{tabular}

(1) Insufficient data on electricity consumption does not permit a reasonable estimate of fuel consumption. 
FIGURE 1. Production of kiln dried lumber of various species during 1985 in West Virginia as a percentage of total kiln dried lumber produced (Armstrong 1987).

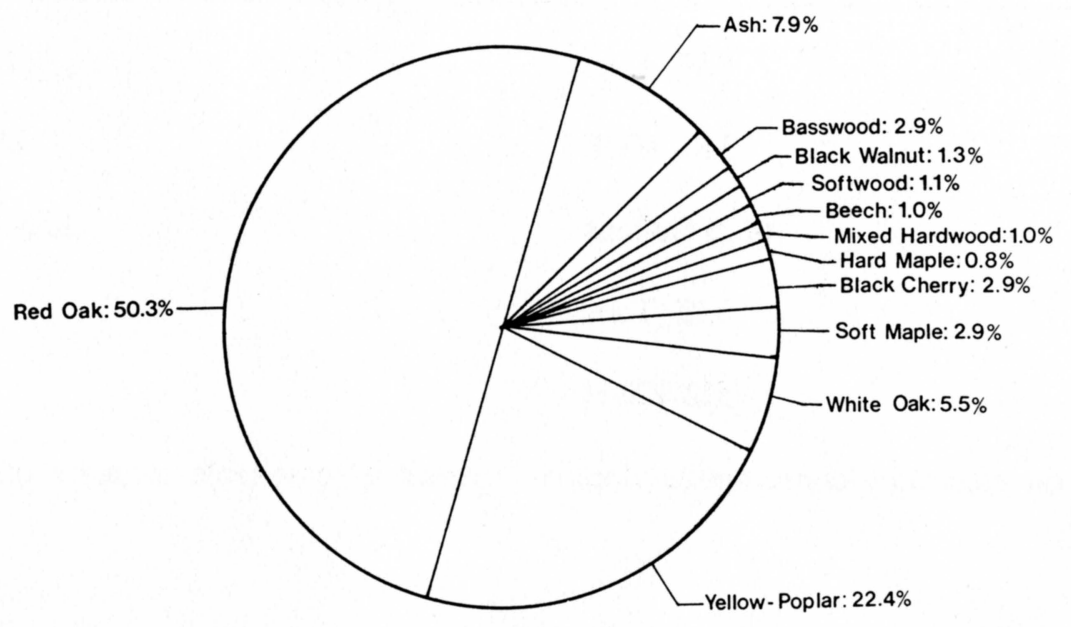


FIGURE 2. Number of mills using each type of fuel or combination of fuels to heat their dry kilns.

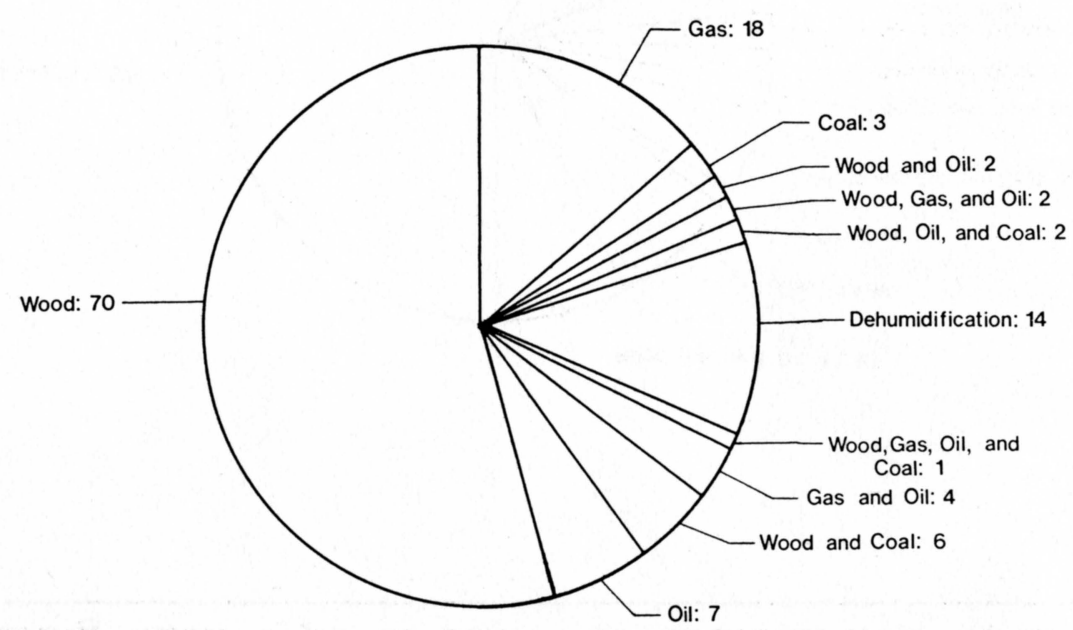


FIGURE 3. Production of lumber kiln dried annually (in million board feet) using each type of fuel or combination of fuels.

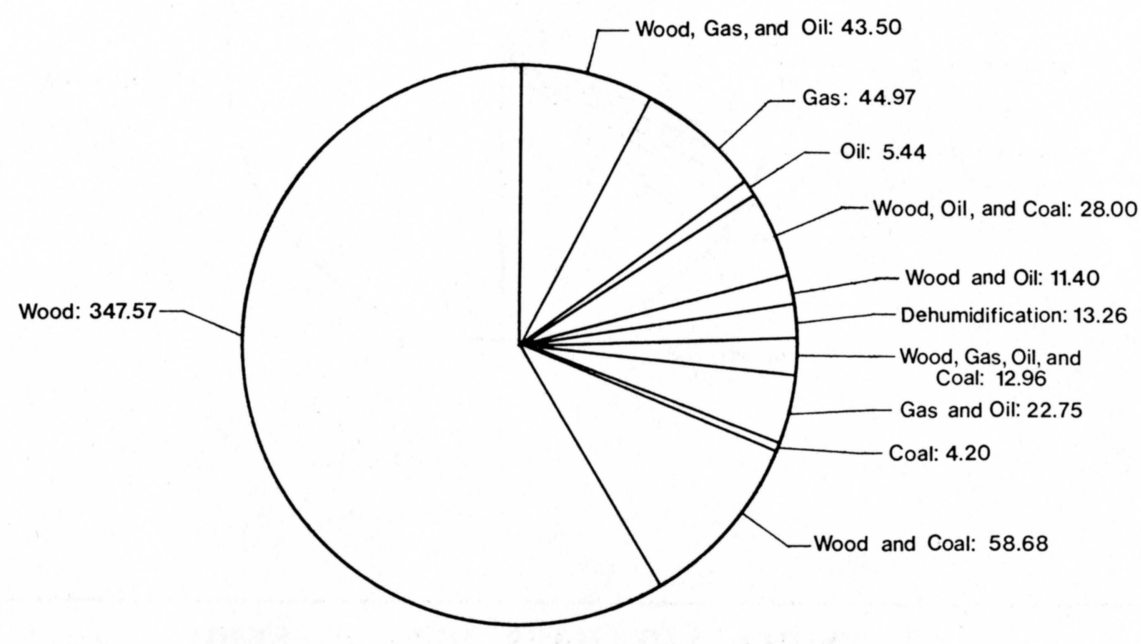


FIGURE 4. The region included in the study and the areas into which it was divided.

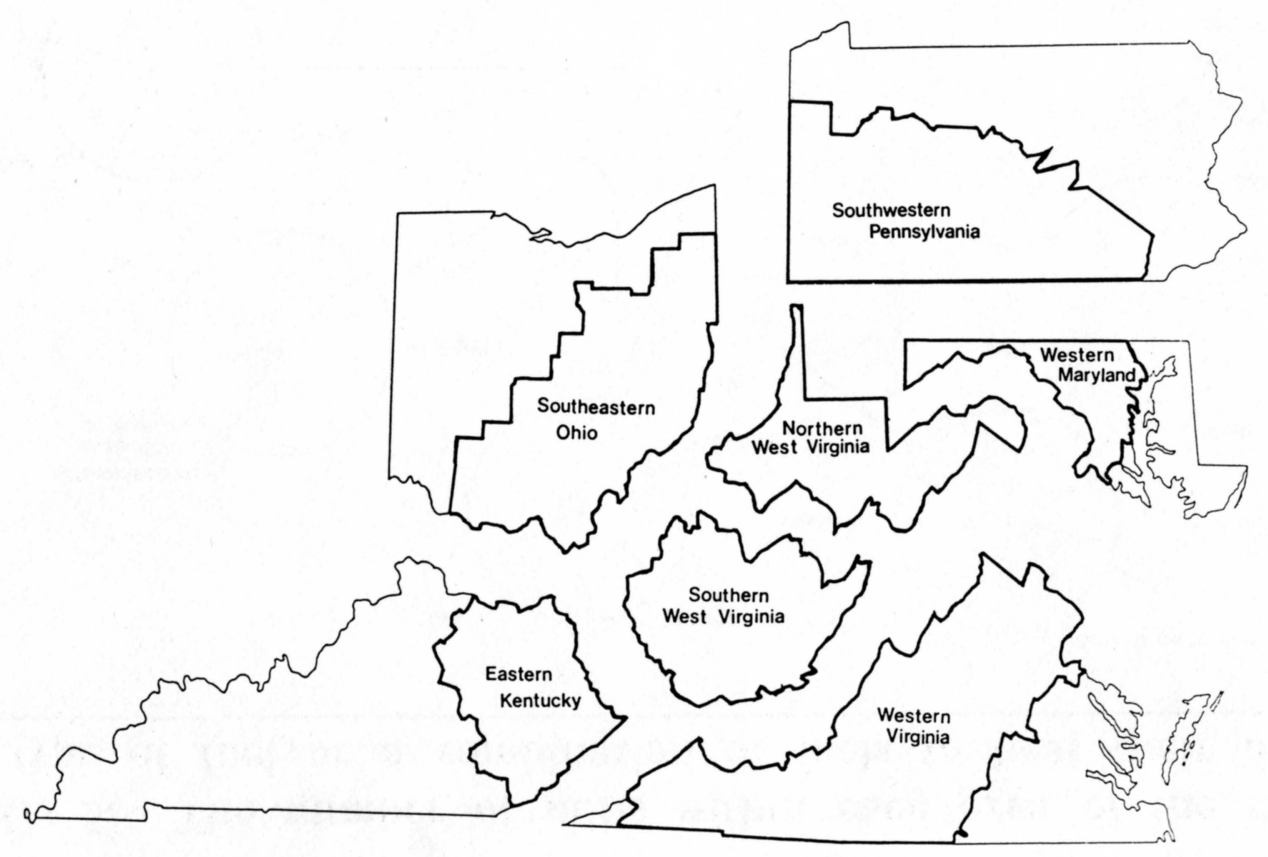


FIGURE 5. The number of mills within each area of the region using each type of fuel or a combination of fuels to heat their dry kilns.

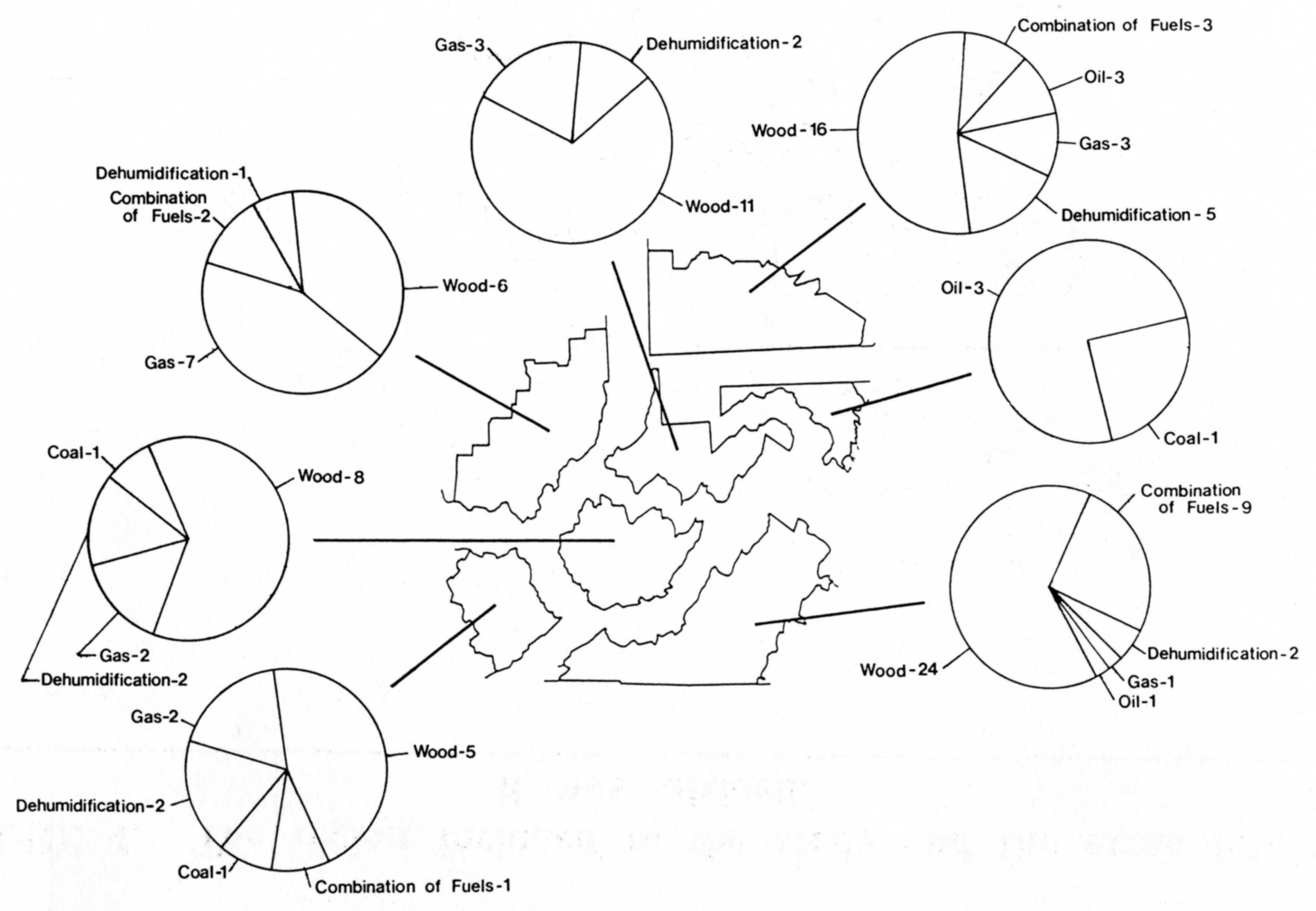


FIGURE 6. Production of lumber kiln dried annually (in million board feet) using each type of fuel or combination of fuels.

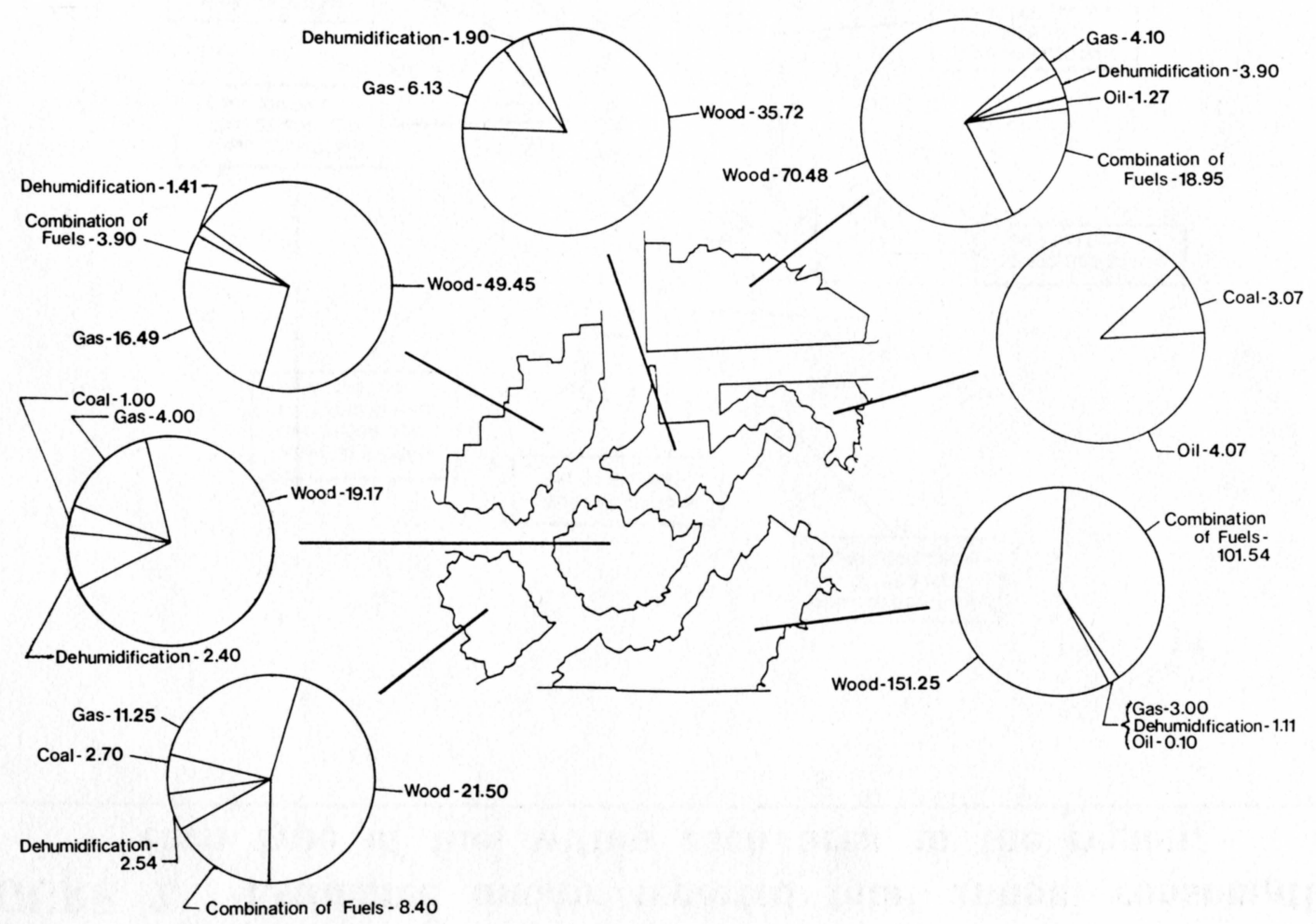


FIGURE 7. Estimated and/or reported total annual consumption of each type of fuel within each area in the region.

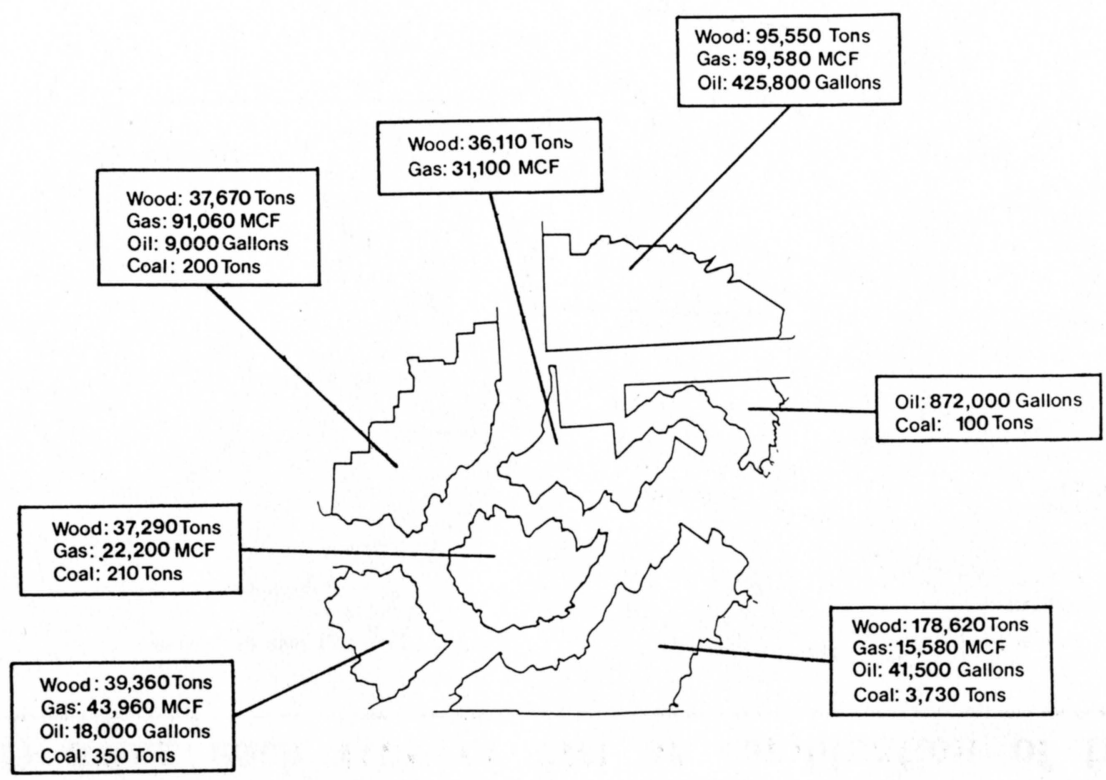




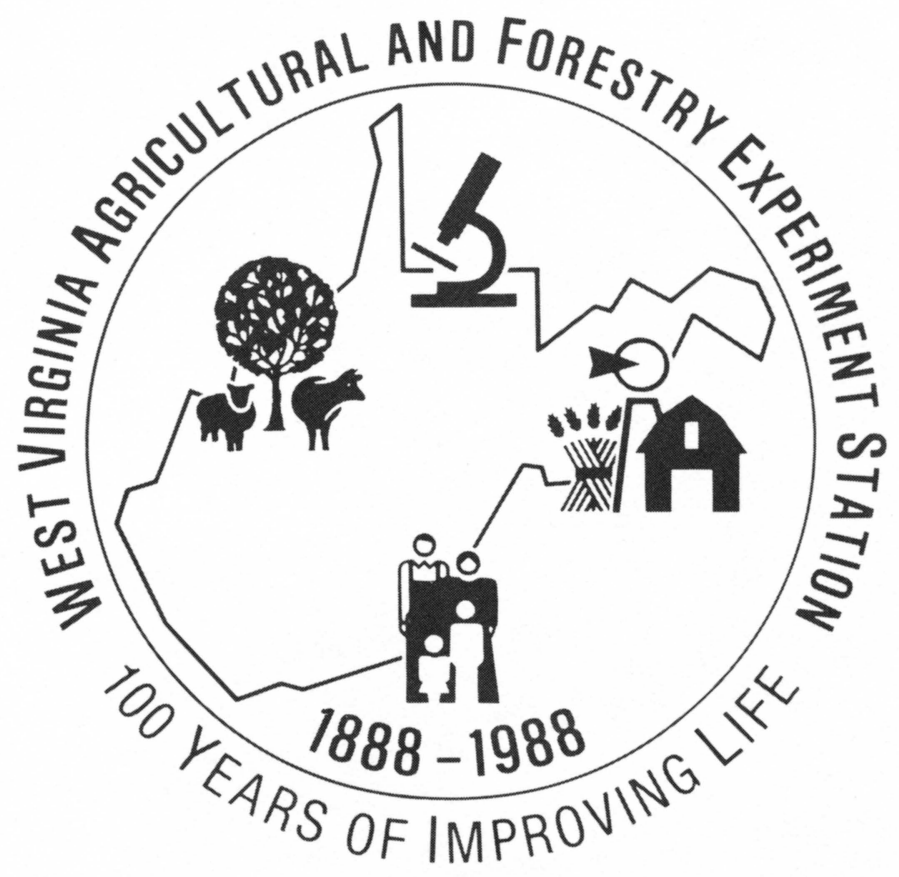


878-3051 